\title{
MODERN CONCEPTS OF ENERGY-EFFICIENT CIVIL AND RESIDENTIAL BUILDINGS. CASE STUDY: ANALYSIS OF A RESIDENTIAL BUILDING ACCORDING TO NZEB CRITERIA
}

\author{
A. VASILIU, OTILIA NEDELCU, I. C. SĂLIȘTEANU, O. MAGDUN \\ Valahia University of Targoviste, Faculty of Electrical Engineering, Electronics and Informational Technology, Department \\ of Electronics, Telecommunication and Energy Engineering ${ }^{1,2,3,4}$ \\ Email: vasiliu_andone@yahoo.com, otilia.nedelcu@valahia.ro, cornel.salisteanu@ valahia.ro, oliver.magdun@ valahia.ro
}

\begin{abstract}
The oil crisis, the measures taken because of global warming caused by greenhouse gas emissions, the ecological actions carried out globally and the technical progress in the fields of electronics, energy, IT and telecommunications have led to the emergence Passive House concepts in the construction sector, of Passive Solar Building (passive construction based on solar energy), of Net Zero-Energy Building NZEB, of Plus Energy Building, of nearly Zero Energy Building nZEB, of Low-Energy Building, of Green House, of Zero Carbon House, of Smart House, of Healthy buildings and other equivalents or derivatives.

In this paper, these concepts will be cross-debated and the measures adopted at EU level and the influences exerted on the Romanian legislation on the field of civil and residential constructions will be presented.

Based on a case study, a residential construction will be characterized, representative of the current housing stock, in order to assess the degree of compliance with the minimum requirements of a house with low energy consumption, imposed by Romanian legislation in the field.
\end{abstract}

Keywords: Passive House, Net Zero-Energy Building NZEB, nearly Zero Energy Building nZEB, Green House, Smart House, low energy house.

\section{INTRODUCTION}

After the oil crisis of 1973, there was a high interest in the design of new buildings and in the rehabilitation of the old construction fund, according to energy efficiency criteria. Thus, the concepts of Passive House, Passive Solar Building (passive construction based on solar energy), Plus Energy Building, Net Zero-Energy Building NZEB (house with zero net energy consumption), nearly Zero Energy Building nZEB (house with almost zero energy consumption), Low-Energy Building (construction with low energy consumption) were born.

Against the background of the phenomenon of global warming due to massive and uncontrolled releases into the atmosphere of waste and greenhouse gases resulting from the burning of fossil fuels ( $\mathrm{CO} 2$ and other gases, smoke, suspended particles, etc.) converted into $\mathrm{CO} 2$ and the background global environmental actions, increased interest in green buildings such as: Green Building or Green House, Zero Carbon House, and others equivalent.

Technical progress, especially in electronics, energy, IT and telecommunications, has facilitated the automation and remote control of many processes in the fields of energy, civil engineering, thus developing smart grids. Combined with the requirements of the population for increasing comfort, they led to the emergence of the concept of Smart House connected to smart grids or not.

All these concepts that have emerged because of various influences from the near and far environment have been exported to different states and adapted to local or EU legislation.

\section{MODERN CONCEPTS ADOPTED IN THE ENERGY-PERFORMING CIVIL AND RESIDENTIAL CONSTRUCTION SEGMENT}

\subsection{The concept of Passive House}

The concept of Passive House [1] was initiated as a pilot project (Passivhaus) supported by the Passivhaus Institute, Hesse, Germany.

"Passive houses" are those buildings that provide a comfortable climate, with a minimum need for energy for heating or cooling, energy that they produce almost entirely on their own.

The Passive House standard requires the building to meet the following four requirements (according to the Passive House Institute, Germany [2, 4]):

A) Energy demand for space heating the energy demand for space heating must not exceed $15 \mathrm{kWh} / \mathrm{m}^{2} \mathrm{a}$ or a maximum (peak) power demand of $10 \mathrm{~W} / \mathrm{m}^{2}$. In addition, the total energy to be used in all facilities of the building, including heating, cooling, lighting, equipment, hot water, etc. is max. $120 \mathrm{kWh} / \mathrm{m}^{2}$ a for living area per year [3].

B) The total demand for renewable primary energy used for all household applications (heating, hot water, domestic electricity) must not exceed $60 \mathrm{kWh} / \mathrm{m}^{2} \mathrm{a}$.

C) In terms of air tightness, a maximum of 0.6 air changes per hour of the enclosure volume.

D) Thermal comfort must be met for all living areas throughout the year.

All the above criteria are achieved by implementing the 5 principles of the Passive Energy Conservation House [2]: 
- Quality thermal insulation of all opaque components of the outer envelope of the building (heat transfer coefficient (U-value) max. $\left.0.15 \mathrm{~W} /\left(\mathrm{m}^{2} \mathrm{~K}\right)\right)$ [2].

- High quality windows with very high thermal resistance $\mathrm{R}$ (heat transfer coefficient (U-value) of max. $0.85 \mathrm{~W} /$ $\left.\left(\mathrm{m}^{2} \mathrm{~K}\right)\right)$ [2].

- Ventilation with heat recovery (at least $75 \%$ of the heat in the exhaust air must be transferred to fresh air) [2].

- Tightness of the building: The construction tires must be, according to the Passive House standard, extremely tight compared to a conventional construction.

\section{- Absence (minimization) of thermal bridges.}

\subsection{The concept of zero-energy building (ZEB)}

The concept of zero-energy building (ZEB) [5] is also known as zero-energy building ZE or net-zero energy building NZEB.

The building with zero net energy consumption (NZEB), is a building that during a year does not use more energy than it generates (where the total annual amount of energy consumed is less than or equal to the amount of predominantly renewable energy created on site or nearby). The annual energy balance between imported energy and exported energy must be $\mathbf{0} \mathbf{~ k W h} / \mathbf{m}^{\mathbf{2}} \mathbf{a}$.

A similar concept, approved and implemented by the European Union and other countries, is nearly Zero Energy Building ( $n Z E B)$.

\subsection{The concept of Energy Plus House}

The concept of Energy Plus House [6] is like both Passive House and NZEB's net-zero energy building but emphasizes the NZEB's approach to producing energy in one year more than it consumes.

The Energy Plus House concept is more than just a method of producing green homes - it is an integrated ecological and architectural concept, designed to be superior to lowenergy, zero-energy NZEB or Passive House projects.

Thus, for an Energy Plus house the annual energy consumption is of maximum $25 \mathrm{kWh} / \mathrm{m}^{2}$ a (compared to NZEB of $0 \mathrm{kWh} / \mathrm{m}^{2} \mathrm{a}$ and of $120 \mathrm{kWh} / \mathrm{m}^{2} \mathrm{a}$ for Passive House).

\subsection{The Green Building concept (eco building, sustainable building)}

The concept of Green Building [7-8] or green building or sustainable building, refers to three aspects:

- $\quad$ to the building technology and materials,

- to the processes with implications on the environment that take place in the building,

- $\quad$ to the efficient use of resources throughout the construction life cycle.
Reducing the impact on the environment is the main objective of the concept of green building, achieved through actions on:

- efficient use of renewable energy resources, sun, water, and other resources,

- reducing environmental degradation by minimizing waste, toxic substances and pollution resulting from the operation of the building,

- protecting the life and health of the people who live in it (common concept with that of the healthy building).

Green, ecological buildings are designed and located in the field based on principles of maximum efficiency of use of available resources:

- sunlight (active solar photovoltaic or thermal installation for heating and DHW, passive solar elements such as high efficiency windows, building orientation, etc.),

- natural shading, decorative elements or even as building elements (plants and trees for shading or for green facades and roofs),

- wind energy,

- energy of waterfalls,

- geothermal or soil energy (for air conditioning),

- construction materials with low environmental impact.

\subsection{The concept of Smart Home}

The concept of Smart Home or Home Automation [9] is based on home automation systems that will monitor and / or control locally, via $\mathrm{Wi}-\mathrm{Fi}$ or via the Internet all installations, systems and home appliances that are integrated in a IoT (Internet of Things) smart network.

The word "smart" in "smart home" refers to the fact that the system is aware of the status of its devices, based on ICT (information and communication technology) protocols and network connections.

Smart homes can be easily integrated into a smart grid of smart grid utilities.

The concept of smart home also carries with it disadvantages related mainly to computer attacks (hacking) with the possible invasion of privacy and intimacy.

\subsection{The concept of Healthy building}

The concept of Healthy building refers to an area that supports and promotes the physical, psychological and social health and well-being of people in the building and in the built environment [10].

The Healthy building can be seen as the next generation of green buildings that, in addition to ecologically responsible (green house) and energy-efficient building concepts (nZEB building), also integrates new concepts that are focused on welfare and performance of building occupants. 
In 2017 year, Harvard Public Health School T.H. Chan School of Public Health has published the 9 foundations of a healthy building [11]:

1) ventilation,

2) indoor air quality,

3) thermal health (thermal comfort),

4) humidity,

5) dust and pests,

6) safety and security,

7) water quality,

8) noise pollution.

9) lighting and view.

Following the case study, conducted in this paper, we propose to add the 10th foundation for a healthy home:

10) the level of electromagnetic pollution [12].

Modern, smart houses, equipped in abundance with household appliances and automation (with production of electromagnetic waves or Wi-Fi communications), can raise the level of electromagnetic fields beyond the limits allowed by the technical rules in force.

\subsection{The concept of nearly Zero Energy Building nZEB}

The concept of nearly Zero Energy Building nZEB is the reinterpretation of the concept of low-energy house and derived from the net concept of Zero Energy Building (NZEB).

As a single European movement to reduce energy consumption and emissions, common legislation on the energy performance of buildings was approved in 2002 (Directive 2002/91 / EC).

Subsequently, the legislation was strengthened by Directive 2010/31 / EU (energy performance of buildings) [13], Directive 2012/27 / EU (energy efficiency of buildings) [15], amended by Directive (EU) 2018/844 [16].

Thus, at EU level, the concept of nearly Zero Energy Building nZEB [13], [14], [18] has emerged and is being implemented in 28 Member States.

Directive 2010/31 / EU on the energy performance of buildings (consolidated version) requires that:

"all new public buildings must be of the nZEB type by 2018 ,

- all new buildings (public or residential) are of the nZEB type by the end of 2020" [13].

The concept of nearly Zero Energy Building nZEB was redefined in 2016 to characterize low-energy houses and according to Recommendation (EU) 2016/131 (on the promotion of buildings with energy consumption almost equal to zero nZEB) [18] involves:

"nZEB is a construction with a very high energy performance,

- $\quad$ the energy requirement must be almost zero (or very low) and be covered, mainly, with energy from renewable sources (arranged on site or in the vicinity)" [18]. It can be concluded that classical energy sources (based on fossil fuels) can also be used to a lesser extent.

According to Directive 2010/31 / EU [13] as amended by Directive (EU) 2018/844 [16], 'the energy performance of a building is determined on the basis of calculated or actual energy consumption and reflects the typical energy consumption for [16]:

- $\quad$ space heating,

- space cooling,

- domestic hot water production,

- ventilation,

- built-in lighting,

- $\quad$ as well as for other technical building systems.

In accordance with Directive 2010/31 / EU, art. 7 [13], EU Member States must "determine (in accordance with the procedure and methodology set out in the Directive) and impose minimum energy performance requirements" [16] in the territory of that State.

Commission Recommendation (EU) 2016/1318 of 2016 [19] stipulates for the horizon 2020, for the geographical area "continental - Zone 3" in which Romania falls, the following energy performance criteria of an nZEB construction, in terms of energy need:

- „for offices: net primary energy $40-55 \mathrm{kWh} /$ $\mathrm{m}^{2} \mathrm{a}$, meaning primary energy $85-100 \mathrm{kwh} / \mathrm{m}^{2} \mathrm{a}$ covered with energy from renewable sources produced on site in the amount of min. $45 \mathrm{kwh} /$ $\mathrm{m}^{2} \mathrm{a}$,

- a single-family house: net primary energy 20 - 40 $\mathrm{kWh} / \mathrm{m}^{2} \mathrm{a}$, meaning primary energy $50-70 \mathrm{kwh}$ $/ \mathrm{m}^{2} \mathrm{a}$ covered with energy from renewable sources produced on site in the amount of min. 30 $\mathrm{kwh} / \mathrm{m}^{2} \mathrm{a} "$ [19].

\subsection{Implementation in Romania of the nZEB concept (low energy building)}

In accordance with the EU Directives, the Romanian competent organisms in the field of energy efficiency have issued laws (Law 1372 / 2005 - energy performance of buildings [20], Law 121/2014 on energy efficiency [21] and others), specific norms (Mc-001/2006 Methodology for calculating energy performance [22], SR-1907/1997, SR-1907/2014 Calculating heat requirements [23], C $107 / 2005$ Norm for thermotechnical calculation of construction elements [24-26], Order 386 of 2016 regarding the amendment $\mathrm{C}-10 / 2005$ [17]) and national implementation plans nZEB.

According to Order 386/2016 [17], it is found that the minimum requirements for the classification of a building in the nZEB category in terms of energy consumption are differentiated according to:

climate zone,

- building category, 
- $\quad$ the year in which the classification is made.

The value of net primary energy is not specified, nor is the value or obligation to use energy from renewable sources produced on site or nearby. Only the value of primary energy expressed in $\mathrm{kWh} / \mathrm{m}^{2} \mathrm{a}$ is specified.

For example, for an individual residential building, located in Ploiești, Prahova (Climate Zone II), for 2020, the energy requirements for the category of low energy buildings nZEB are:

- $\quad$ Primary energy max. $111 \mathrm{kWh} / \mathrm{m}^{2}$,

- $\quad \mathrm{CO} 2$ emissions max. $30 \mathrm{~kg} / \mathrm{m}^{2}$.

\section{STUDY: ANALYSIS OF A RESIDENTIAL BUILDING ACCORDING TO nZEB CRITERIA}

\subsection{Input data}

The classification of the residential building according to the criteria of the house with low energy consumption nZEB, was made based on the results of previous audits that aimed to characterize the building in terms of electroenergetic and thermo-energetic, in terms of electromagnetic compatibility and the impact of the building on the environment and residents.

- Building type: residential, year of construction: 2009,

- Location: Ploiești, Prahova, Climate zone II,

- Layout: ground floor, first floor, unheated insulated attic,

- Total usable area: $138.15 \mathrm{~m} 2$,

- Tire insulation: exterior wall insulation with thick expanded polystyrene. $5 \mathrm{~cm}$, mineral wool bridge insulation $20 \mathrm{~cm}$ thick.

- Exterior windows and doors with plastic frame with 5 rooms, 2 layers of low-E glass,

- Interior lighting with low energy / LED lamps,

- Heating system: natural gas boiler, underfloor and radiator heating, thermostat set at $23.5^{\circ} \mathrm{C}$, for the entire heating period,

- Ventilation system: natural, uncontrolled,

\subsection{Audit results}

During the thermo-energetic audit, thermal bridges were identified at the intersection of the floors with the external walls because the insulation with expanded polystyrene with a thickness of $5 \mathrm{~cm}$ is not sufficient (Figure 1, Figure 2):

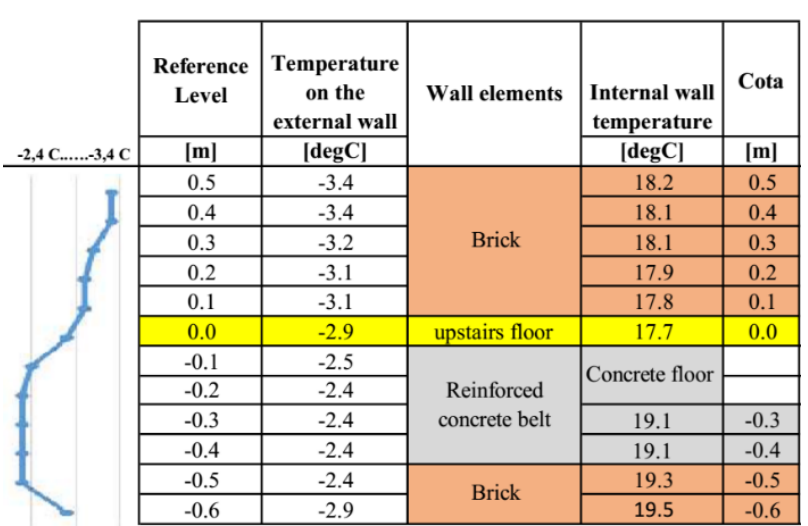

Figure 1. Identification of thermal bridge by measurements

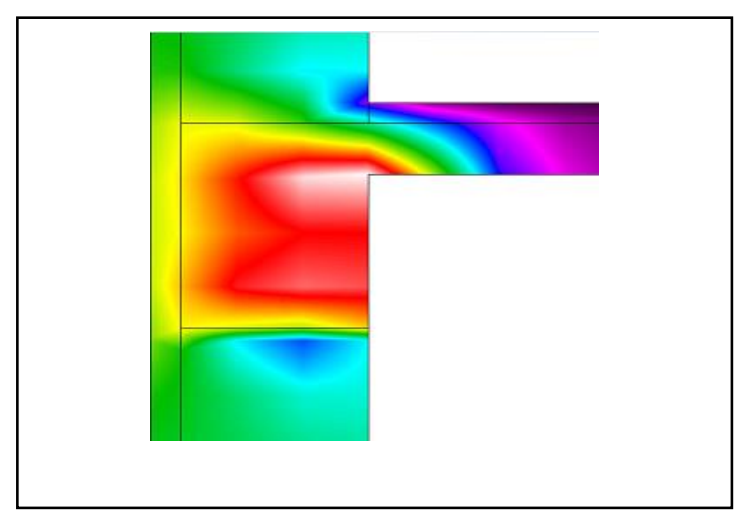

Figure 2. Leakage flow simulation in the area of the reinforced concrete belt

An area with electromagnetic pollution was identified following the audits on electromagnetic compatibility and the impact of the building on the environment and residents. There was an increase in the level of electromagnetic radiation in the kitchen area above the allowed limits (according to the Order of the Minister of Public Health no. 1193/2006 - "Rules on limiting the exposure of the general population to electromagnetic fields"[27]), produced by household appliances (microwave oven). In other areas of the building, levels have been identified that are alarmingly close to the permitted limits, produced by Wi-Fi communication equipment, mobile phones and mobile phone antennas.

Thus, the microwave oven has electromagnetic field leaks up to a distance of $1.5 \mathrm{~m}$, above the limits imposed by Order 1193, after which the electromagnetic field level falls within the norms, as follows:

- At a distance of $0.5 \mathrm{~m}$ it causes a SAR absorption rate of the electromagnetic field in the whole human body of $1,495 \mathrm{~W} / \mathrm{kg}, 18.7$ times higher than the maximum recommended dose $(0.08 \mathrm{~W} /$ $\mathrm{kg}$ for the whole body) and has a leakage field with electric field strength $\mathrm{E}=23.4 \mathrm{~V} / \mathrm{m}$ (value that falls within the norms). However, it is an important level, equivalent to the issuance of 166 smart mobile phones (year of manufacture 2019) (Figure 3).

- At a distance of $1.5 \mathrm{~m}$ the level of electromagnetic radiation falls within the norms but remains an 
important electric field of $7.012 \mathrm{~V} \mathrm{/} \mathrm{m}$, the equivalent of 50 smart phones.

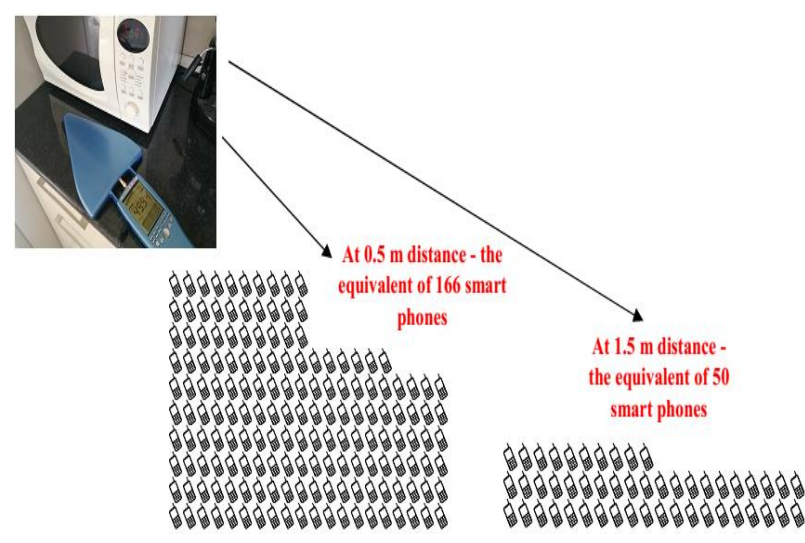

Figure 3. The level of the electromagnetic field of escape of the microwave oven

\subsection{Analysis according to $\mathrm{nZEB}$ criteria}

In accordance with Directive 2010/31 / EU as amended by Directive (EU) 2018/844 [15], the energy performance of the building under study may be determined based on an energy efficiency calculation or based on actual energy consumption for heating / space cooling, domestic hot water production, lighting, ventilation, and other technical systems of the building.

The case study used actual electricity consumption for built-in lighting and other technical systems (gas central heating, alarm system, smoke and gas sensors, Wi-Fi, etc.) and natural gas consumption, related to the period 2017 2020.

Contour energy balance, according to the electro-energetic and thermo-energetic audits performed (annual consumption averages recorded in the period 2017 - 2020) and based on the Energy Efficiency Guide for Buildings I, results:

- Average annual electricity consumption: 4100 kWh / a, of which: electricity for lighting: 422 $\mathrm{kWh} / \mathrm{a}$,

- Average annual consumption of natural gas: 1792 $\mathrm{m}^{3}$ / a, equivalent to $19272 \mathrm{kWh} / \mathrm{a}$.

- Total primary energy (heating and lighting): $19694 \mathrm{kWh} / \mathrm{a}$.

- Greenhouse gas emissions due to consumption of:

- electricity: 1.2 tonnes / year $\mathrm{CO}_{2}$ equivalent, (with a conversion rate of $289.85 \mathrm{gCO}_{2} / \mathrm{kWh}$, conf. [28]),

- natural gas: 3,490 tons / year $\mathrm{CO}_{2}$ equivalent, (with conversion rate of $181.08 \mathrm{gCO}_{2} / \mathrm{kWh}$, conf. [29]).

- $\quad$ Total greenhouse gas emissions: 4.69 tons / year $\mathrm{CO}_{2}$ equivalent.
Primary energy consumption and $\mathrm{CO}_{2}$ emissions related to the surface of the dwelling:

- Primary electricity: $19694 \mathrm{kWh} / \mathrm{a} / 135.15 \mathrm{~m}^{2}=$ $142.555 \mathrm{kWh} / \mathrm{m}^{2} \mathrm{a}$

- CO2 equivalent gas emissions: $4690 \mathrm{~kg} / \mathrm{a} /$ $135.15 \mathrm{~m}^{2}=34.7 \mathrm{kgCO}_{2} / \mathbf{m}^{2} \mathbf{a}$.

According to Order 386 of 2016 [17], for an individual residential building, located in Ploiești, Prahova (Climate Zone II), for 2020, the energy requirements for the nZEB category are:

- Primary energy max. $111 \mathrm{kWh} / \mathrm{m}^{2}$,

- $\quad \mathrm{CO} 2$ emissions max. $30 \mathrm{~kg} / \mathrm{m}^{2}$.

The comparison between the real energy consumption of the building under study and the limits imposed by Order $386 / 2016$ for the period 2010 - 2020, for a building to be declared nZEB is presented in Figure 4:

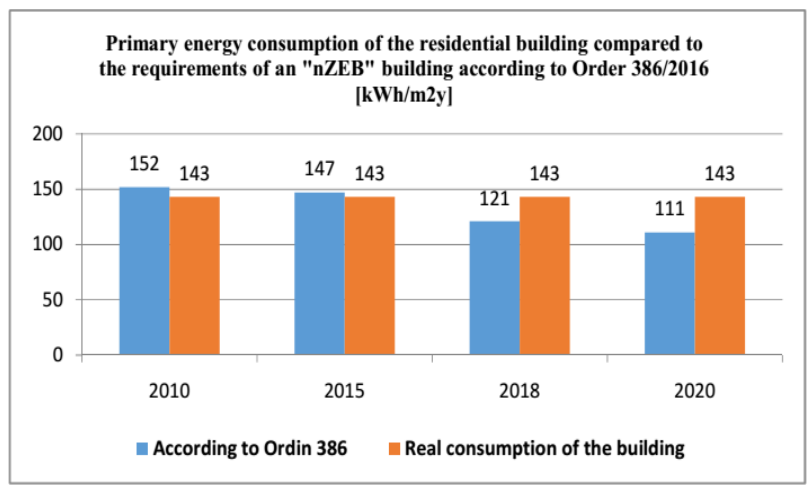

Figure 4. Real energy consumption of the construction versus limits imposed by Order 386/2016

\subsection{Conclusions on the case study:}

$\checkmark$ The residential building subject to the case study does not fall into the category of houses with low energy consumption nZEB at the level of 2020 for Romania (according to Order 386 of 2016).

$\checkmark$ The energy framing of the building was not based on the intrinsic energy performance of the building but was determined based on the actual consumption of electricity and gas, where the behavior of the occupants (relative to the set temperature, the heating of all spaces even unoccupied and the ventilation of the rooms uncontrolled) brings an important subjective factor.

$\checkmark$ However, it is to be appreciated that from an energy point of view it is a house with energy consumption close to the requirements for inclusion in nZEB for 2020. Thus, it falls within the limits imposed for houses with low energy consumption nZEB in 2015 (primary energy $147 \mathrm{kWh} / \mathrm{m}^{2} \mathrm{c}$, respectively $\mathrm{CO}_{2}$ emissions $42 \mathrm{~kg} / \mathrm{m}^{2} \mathrm{an}$ ).

$\checkmark$ To meet the requirements of an nZEB 2020 house:

- rehabilitation works should be carried out on the basis of an energy audit,

- residents' behavior on energy savings should be reconfigured. 
$\checkmark$ The building is equipped with elements and technologies specific to Passive House concepts of energy conservation and energy efficiency (insulation, quality windows, sealing, reduction of thermal bridges, etc.) and ensuring a comfortable climate (thermal comfort, air quality). However, thermal bridges were found at the intersection of the exterior walls with the floor, as a result of insufficient insulation of the building envelope, and therefore, thermal rehabilitation works are required.

$\checkmark$ The building can also be included in the concept of Healthy building because it meets all 9 foundations of a healthy building: ventilation, air quality, thermal health, humidity, dust and pests, safety and security, water quality, noise, lighting, and view.

However, against the background of the concept of Healthy Building, and following the audit on the impact of the building on the environment, it was found an electromagnetic pollution caused by a microwave oven that has leakage of electromagnetic radiation beyond the permitted limits. Electromagnetic shielding or equipment replacement measures are required.

$\checkmark$ To truly fulfill the concept of Healthy building, the standards should also monitor the level of electromagnetic pollution inside buildings.

\section{GENERAL CONCLUSIONS}

Globally, at the EU and national level, several concepts are being circulated about new construction or the rehabilitation of the existing housing stock. All concepts have as final goal the improvement of living conditions or professional activity. Some concepts give priority to energy conservation and energy efficiency, others to reducing the impact on the environment or on comfort conditions and ensuring the health of occupants. There is no perfect concept that meets all the requirements.

In the design and execution of a building must coexist principles and foundations specific to all these concepts, with emphasis on those of major interest, under the conditions imposed by the geo-political position, climate, access to resources, budget, etc.

The European Union has officially imposed at Community level (see Directive 2010/31 / EU and others) the concept of near-zero energy construction or the low-energy house nZEB, although there are several concepts in Europe.

Romania has adapted EU norms and imposed energy performance standards and $\mathrm{CO}_{2}$ emissions specific to the development of the national energy park, the existing construction fund, climate conditions, etc., has proposed that all new public buildings must be of the nZEB type by 2018 and all new buildings (public or residential) to be of the nZEB type by the end of 2020. For the existing housing fund has implemented plans for the rehabilitation and use of renewable energy (eg the "Green House" program, PV installations, etc.)

\section{REFERENCES}

[1] https://en.wikipedia.org/wiki/Passive_house

[2] https://passivehouse.com/02_informations/02_passi ve-house-requirements/02_passive-houserequirements.htm

[3] https://www.passivehouseacademy.com/downloads/ Passive\%20House\%20Retrofit\%20Guidelines.pdf, Retrofit Passive House,

[4] PHIUS + 2015: Passive Building Standard North America Guidebook (PDF), www.phius.org, 2018.

[5] https://en.wikipedia.org/wiki/Zero-energy building

[6] https://en.wikipedia.org/wiki/Energy-plushouse\#Technical_approach

[7] https://en.wikipedia.org/wiki/Green_building

[8] http://www.epa.gov/greenbuilding/pubs/components .htm, Green Building Home, 2009

[9] https://en.wikipedia.org/wiki/Home automation

[10] https://en.wikipedia.org/wiki/Healthy building

[11] Allen, Joseph G; Bernstein, Ari (2020). "The 9 Foundations of a Healthy Building" (PDF). Foundations. Retrieved 2020-12-17.,

[12] https://www.who.int/news-room/q-adetail/radiation-electromagnetic-fields

[13] Directiva 2010/31/UE a Parlamentului European și a Consiliului din 19 mai 2010 privind performanța energetică a clădirilor,

[14] https://ec.europa.eu/energy/topics/energyefficiency/energy-efficient-buildings/nearly-zeroenergy-buildings en

[15] Directiva 2012/27/UE a Parlamentului European si a Consiliului din 2012 privind eficiența energetică a clădirilor,

[16] Directiva (UE) 2018/844 a Parlamentului European si a Consiliului din 30 mai 2018 de modificare a Directivei 2010/31/UE privind performanta energetică a clădirilor si a Directivei 2012/27/UE privind eficiența energetică,

[17] Ordin 386 din 2016 pentru modificarea şi completarea Reglementării tehnice Normativ privind calculul termotehnic al elementelor de construcţie ale clădirilor", indicativ C 107-2005,

[18] Recomandarea (UE) 2016/1318 a Comisiei din 29 iulie 2016 privind orientările pentru promovarea clădirilor al căror consum de energie este aproape egal cu zero nZEB, precum şi cele mai bune practici pentru a asigura faptul că, până în 2020, toate clădirile noi vor fi clădiri al căror consum de energie este aproape egal cu zero,

[19] Recomandarea (EU) 2016/1318 din 2016,

[20] Lege 1372 din 2005 privind performanta energetica a clădirilor,

[21] Lege 121 din 2014 cu privire la eficienta energetica,

[22] Mc-001 / 2006 Metodologie calcul performanta energetica,

[23]SR-1907 / 1997, SR-1907 / 2014 Necesarul de căldura de calcul,

[24] C-107/2005 Normativ privind calculul termotehnic al elementelor de construcţie ale clădirilor,

[25] Delia D'Agostino si altii, Synthesis Report on the National Plans for Nearly Zero Energy Buildings (NZEBS), JRC Science for Policy Report of European Commission, 2016,

[26] Diana Tenea si altii, EPBD implementation in Romania, Status in December 2016, revision 2018, www.mdrap.ro , si https://epbd-ca.eu/caoutcomes/outcomes-2015-2018/book2018/countries/romania 
[27] Etichetă energie electrică furnizată clienţilor în regim concurenţial în anul 2018, Enel Energie Muntenia S.A., contacteem.ro@enel.com,

[28] RAPORT MONITORIZARE PLAN de ACȚIUNE privind ENERGIA DURABILA Municipiul DEVA, https://mycovenant.eumayors.eu/storage/web/mc_co
venant/documents/25/CWpHwCZye018grzv7At7wO zkZnGRJcFC.pdf

[29] ORDIN nr. 1193 din 29 septembrie 2006 pentru aprobarea Normelor privind limitarea expunerii populatiei generale la câmpuri electromagnetice de la $0 \mathrm{~Hz}$ la $300 \mathrm{GHz}$, Ministerul Sănătății Publice, 2006, 